\title{
Herbicidal bioactivity of natural compounds from Lantana camara on the germination and seedling growth of Bidens pilosa ${ }^{1}$
}

\author{
Diego Medeiros Gindri ${ }^{2}$, Cileide Maria Medeiros Coelho ${ }^{3}$, \\ Virgilio Gavicho Uarrota ${ }^{4}$, Andrey Martinez Rebelo ${ }^{5}$
}

\section{ABSTRACT}

Lantana camara (L.) is considered one of the main invasive plants, and the allelochemicals produced by this species can be defined as bioactive secondary metabolites that mediate chemical interactions between the plant and other organisms and, therefore, play an important role in its succession and establishment. The present study aimed to investigate the effect of L. camara aqueous extracts on the germination and growth behavior of Bidens pilosa (L.) by evaluating physiological parameters (germination rate, germination speed index, seedling performance and structure and membrane integrity), as well as the extract metabolic profile. The extract reduced the germination speed index and seedling growth rate and promoted abnormalities in the geotropism and root development in both populations. The third germination phase was highly affected (more than the phases I and II). Lantadene A and B are the possible compounds conferring the herbicidal properties, and the L. camara extract has a potential to be used in the development of a new environmentally-friendly herbicide.

KEYWORDS: Lantadene, seed physiology, phytotoxicity, bioactive compounds.

\section{INTRODUCTION}

Allelochemicals are mostly secondary metabolites, released into the environment as exudates, volatile and/or residues of the decomposition of plant tissues. Allelopathy provides the opportunity for research with new chemical entities with prominent herbicidal properties and lower impacts on the

\section{RESUMO}

Bioatividade herbicida de compostos naturais de Lantana camara na germinação e crescimento de plântulas de Bidens pilosa

Lantana camara (L.) é considerada uma das principais plantas invasoras, e os aleloquímicos produzidos por essa espécie podem ser definidos como metabólitos secundários bioativos que medeiam interações químicas entre a planta e outros organismos e, portanto, desempenham papel importante na sucessão e estabelecimento. Objetivou-se investigar o efeito de extratos aquosos de L. camara sobre a germinação e crescimento de Bidens pilosa (L.), avaliandose parâmetros fisiológicos (taxa de germinação, índice de velocidade de germinação, desempenho e estrutura de plântulas e integridade de membranas), bem como o perfil metabólico do extrato. O extrato reduziu o índice de velocidade de germinação e a taxa de crescimento de plântulas e promoveu anormalidades no geotropismo e no desenvolvimento radicular em ambas as populações. A terceira fase da germinação foi altamente afetada (mais que as fases I e II). Lantadene A e B são os possíveis compostos que conferem as propriedades herbicidas, e o extrato de L. camara tem potencial para ser usado no desenvolvimento de um novo herbicida ecologicamente correto.

PALAVRAS-CHAVE: Lantadene, fisiologia de sementes, fitotoxicidade, compostos bioativos.

environment and humans than synthetic compounds commonly used in agriculture (Reigosa et al. 2013).

Kohli et al. (1997) suggest three proposals, whereby allelopathy could be manipulated in weed management: transfer of genes responsible for the synthesis of allelochemicals between crops; use of crop rotation, combining successor crops capable of reducing the population of weeds by means of their potential

1. Received: Mar. 18, 2019. Accepted: Aug. 12, 2019. Published: Nov. 13, 2019. DOI: 10.1590/1983-40632020v5057746.

2. Companhia Integrada de Desenvolvimento Agrícola de Santa Catarina, Departamento de Defesa Vegetal, Lages, SC, Brasil. E-mail/ORCID: diegogindri@gmail.com/0000-0002-3930-287X.

3. Universidade do Estado de Santa Catarina, Centro de Ciências Agroveterinárias, Departamento de Agronomia, Lages, SC, Brasil.E-mail/ORCID: cileidecoelho@yahoo.com.br/0000-0001-9528-7371.

4. Pontificia Universidad Católica de Valparaiso, Escuela de Agronomia, La Palma, Quillota, Chile. E-mail/ORCID: uaceleste@yahoo.com.br/0000-0002-2974-1625.

5. Empresa de Pesquisa Agropecuária e Extensão Rural de Santa Catarina, Unidade de Ensaios Químicos e Cromatográficos, Itajaí, SC, Brasil. E-mail/ORCID: andrey@epagri.sc.gov.br/0000-0003-3075-3639. 
allelopathic; and use of allelochemicals obtained from plants as herbicides, being a safe and effective method, since they are natural products, biodegradable and do not persist in the soil as pollutants.

Natural compounds capable of suppressing the weed growth have been the subject of studies with the main goal of developing new natural herbicides, as they are often considered as environmentallyfriendly and easily biodegradable (Lima et al. 2018). According to Cantrell et al. (2012), in the USA, from 1997 to $2010,69.3 \%$ of the new active ingredients registered at the Environmental Protection Agency derived from natural products.

Lantana camara L. (lantana) is a perennial aromatic shrub of the Verbenaceae family, considered as one of the main invasive plants (Day et al. 2003, Wang et al. 2011). Allelopathy is an important factor in the success of invasion and establishment of exotic plants, which suggests the possibility of studies on the phytotoxicity of its extracts as a basis for the development of a new natural herbicide.

Phytochemicals isolated from L. camara extracts have been regarded to exihibit a range of biological activities against other plant species (Gorla \& Perez 1997, Verdeguer et al. 2009, Hossain \& Alam 2010, Maiti et al. 2010, Mishra \& Singh 2010, Hussain et al. 2011, Kenany \& Darier 2013, Manohar et al. 2017). Among them, 1,8-cineol has been reported in the literature as an important intermediate source for herbicide development. Cineol has significant phytotoxic properties (Romagni et al. 2000, Lana et al. 2006, Kegge \& Pierik 2010). $\beta$-pinene, 1,8-cineol and Dipentene are reported by Mishra (2015) as seed germination inhibitors (Figure 1). L. camara triterpenoids, named as lantadenes (A, B, C, D), have attracted interest because of their cytotoxicity and inhibitory activity on plant growth (Kong et al. 2006). Lantadene A and D from L. camara (Sharma et al. 1980, 1990, 2007) have also been reported in the literature to have a potential biological activity (Latif et al. 2017, Mishra 2015, Kennany \& Darier 2013, Ahmed et al. 2007) (Figure 1).

\section{MATERIAL AND METHODS}

B. pilosa mature seeds were collected in Santa Maria, Rio Grande do Sul state $\left(-29.680266^{\circ}\right.$ $\left.-53.819946^{\circ}\right)$, hereinafter designed as SMA population, and in Lages, Santa Catarina state $\left(-27.807481^{\circ}-50.328805^{\circ}\right)$, hereinafter designed as LAG population, both cities in Brazil. The seeds were homogenized manually and stored in a dry and cold chamber $\left(50 \pm 5 \%\right.$ relative humidity and $8 \pm 2{ }^{\circ} \mathrm{C}$ temperature) until laboratory analysis. Leaves of flowering wild plants of $L$. camara were harvested during the morning, in Lages, then washed using distilled water and dried in an oven with forced air circulation (Lucadema model 80/85; $72 \mathrm{~h} / 40{ }^{\circ} \mathrm{C}$ ). After drying, the leaves were shredded and stored in a dry and cold chamber $(50 \pm 5 \%$ relative humidity and $8 \pm 2{ }^{\circ} \mathrm{C}$ temperature). The extracts were prepared by mixing $10 \mathrm{~g}$ of leaf powder in $90 \mathrm{~mL}$ of water $\left(25^{\circ} \mathrm{C} / 24 \mathrm{~h}\right)$. The mixture was filtered and then centrifuged at 3,600 rpm (Excelsa II $206 \mathrm{BL}$ ), for $10 \mathrm{~min}$. The obtained supernatant (crude extract)
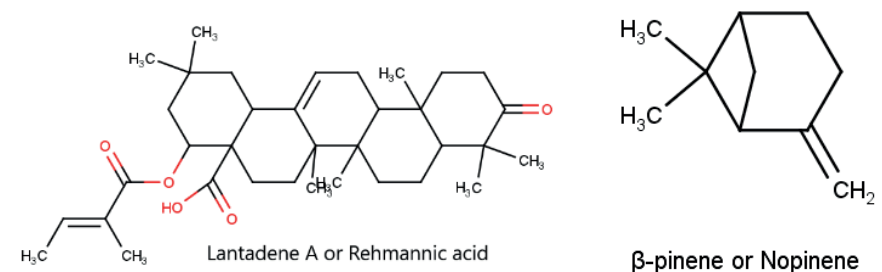

$\beta$-pinene or Nopinene


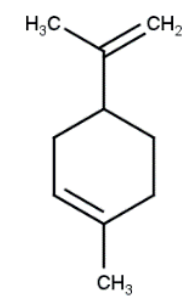

Dipentene or D-Limonene

Figure 1. Chemical structures of two triterpenoids (Lantadene A and D) and three monoterpenes ( $\beta$-pinene, Dipentene and 1,8-cineol) of Lantana camara. Structures created by the co-author Virgílio Uarrota, using the Marvin Sketch Software. 
was diluted in water to obtain different extract concentrations $(0 \%, 1.25 \%, 2.5 \%, 3.75 \%$ and $5.0 \%-\mathrm{v} / \mathrm{v})$.

The seed imbibition curve was obtained using two replicates of 50 seeds for each measured time. Briefly, the seeds were placed in acrylic boxes $(12 \mathrm{~cm} \times 12 \mathrm{~cm})$, on three sheets of germitest paper moistened with water and the extract concentrations, in the proportion of 2.5 times the mass of the dry paper. The boxes were transferred to a BOD germination chamber at $25^{\circ} \mathrm{C}$ and $12 \mathrm{~h}$ of photoperiod. At each time $(3,6,12,18,24,48$ and $72 \mathrm{~h})$, two samples of 50 seeds were taken and their moisture determined by using an oven $\left(105^{\circ} \mathrm{C} / 24 \mathrm{~h}\right)$. By means of the difference of water absorbed between the times, the soaking curve was obtained and, by the difference of humidity between the times, the imbibition curve was obtained.

The seed viability was evaluated by the germination test, in a completely randomized factorial design, where 50 seeds in 4 replicates were sown in acrylic boxes $(12 \mathrm{~cm} \times 12 \mathrm{~cm})$, on three sheets of germitest paper dampened 2.5 times the mass of the dry paper with extracts and water $(0 \%, 1.25 \%, 2.5 \%, 3.75 \%$ and $5.0 \%-\mathrm{v} / \mathrm{v})$. The boxes were kept in a germination chamber (12 h of photoperiod and $25^{\circ} \mathrm{C}$ ). The seeds were exposed to the extracts until the beginning of the phase III of the germination (root protrusion) in distilled water and different concentrations of the extract. Seeds previously exposed in water in the phases I and II were then transferred to boxes containing L. camara extract and those previously exposed to the L. camara extracts were transferred to boxes with water (and vice-versa). At 7 days after sowing, the evaluations were performed.

The vigor by initial seedling growth was evaluated by the germination test, in a completely randomized factorial design. The length of the hypocotyl and roots were measured and the presence of secondary roots evaluated, with results expressed as growth inhibition rate and as presence of secondary roots rate (Nakagawa 1999).

The vigor by germination speed index (GSI) was evaluated by the germination test, in a completely randomized factorial design, by counting, at each $12 \mathrm{~h}$ of the assay, the total number of germinated seeds (root protrusion of $2 \mathrm{~mm}$ ), until a constant number of germinated seeds. The GSI was calculated according to the following equation:

$$
\text { GSI }(\%)=\sum\left(\frac{\mathrm{G}_{\mathrm{S} 1}}{\mathrm{C}_{1}}+\frac{\mathrm{G}_{\mathrm{S} 2}}{\mathrm{C}_{2}}+\ldots+\frac{\mathrm{G}_{\mathrm{Sn}}}{\mathrm{C}_{\mathrm{n}}}\right) * 100
$$

where $\mathrm{C}_{1}$ and $\mathrm{C}_{2}$ represent the first and second count; and $\mathrm{G}_{\mathrm{S} 1}$ and $\mathrm{G}_{\mathrm{S} 2}$ the number of germinated seeds at the first and second count, respectively (Souza Filho et al. 2010).

The vigor by electrical conductivity was evaluated in a completely randomized factorial design, where seeds (100 seeds/4 replicates) were previously weighed and then submitted to imbibition in different extract concentrations, during $1 \mathrm{~h}$. After imbibition, the seeds were washed in distilled water, transferred to a $50 \mathrm{~mL}$ recipient containing water and stored in a BOD chamber $\left(20^{\circ} \mathrm{C} / 24 \mathrm{~h}\right)$. The electrical conductivity was evaluated after $3 \mathrm{~h}, 12$ $\mathrm{h}$ and $24 \mathrm{~h}$, with results expressed in $\mu \mathrm{S} \mathrm{cm}^{-1} \mathrm{~g}^{-1}$ of seeds (Vieira \& Carvalho 1994).

For the Mid-Infrared Vibrational Fourier Transform Spectroscopy (ATR-FTIR) of the leaf powder and extract, an IFS-55 (Opus v. 5.0, Bruker Biospin) spectrometer, with a DTGS detector and a golden gate single reflection diamond attenuated total reflectance (ATR) accessory ( $45^{\circ}$ incidence angle), was used. A background spectrum of the clean crystal was acquired and samples were spread and measured directly after pressing them on the crystal. The spectra were recorded at the absorbance mode of $4,000 \mathrm{~cm}^{-1}$ to $400 \mathrm{~cm}^{-1}$, at the resolution of $4 \mathrm{~cm}^{-1}$. Five replicate spectra (128 co-added scans) were collected for each sample. In the data pre-processing stage, the spectra were normalized and baseline-corrected in the region of interest by drawing a straight line before the resolution enhancement ( $\mathrm{k}$ factor of 1.7), using Fourier self-deconvolution. The assumed line shape was Lorentzian, with a half width of $19 \mathrm{~cm}^{-1}$ (Uarrota et al. 2013).

For the HPLC-MS of leaf extract, an HPLC (1290 UHD - QtoF - LC/MSMS - Agilent) with stationary column (Eclipse Plus C18/RRHO, $100 \mathrm{~mm} \times 2.1$ particle size of $1.8 \mu \mathrm{m}$ ) and two mobile phases composed by acetonitrile and water, acidified with $0.1 \%$ of formic acid and $0.1 \%$ of ammonium formate, respectively, were used, with retention time of $20 \mathrm{~min}$ for sample and two replications for injection.

For data mining and statistics, the data were summarized, subjected to normality (Shapiro-Wilk) and homogeneity (Levene) tests and submitted to analysis of variance, with two independent 
experiments performed. The statistical analysis showed no significant differences between the experiments. Results were presented as mean and standard deviation of all replicates. Where differences were observed, the Dunnett Test $(p<0.05)$ was used as a mean separation test. All statistical analyses were performed in the R software (R Core Team 2017).

\section{RESULTS AND DISCUSSION}

For the seed imbibition curve, the threephase seed germination pattern was observed for all treatments, with a rapid water absorption up to $6 \mathrm{~h}$, a phase of low absorption between $6 \mathrm{~h}$ and $24 \mathrm{~h}$, and a recovery after $24 \mathrm{~h}$ (Figure 2). The results indicate that the osmotic potential of the aqueous solutions of $L$. camara leaves did not interfere in the water absorption of the seeds.

For seed viability and vigor, the germination of the control in the LAG population was higher $(90 \pm$ $3 \%)$ than in the SMA $(42 \pm 2 \%)$ one. The $B$. pilosa germination was not affected by the concentrations of the aqueous leaf extract of L. camara during the germination phase I. However, when exposed to the leaf extract at the germination phase III, the germination was reduced to $70 \pm 6 \%$ and $68 \pm 6 \%$ in the LAG population and to $32 \pm 2 \%$ and $27 \pm 2 \%$ in the SMA population (Figure 3 ).

Seed death was observed only in the SMA population, during the three germination phases. However, it was noticed that the main damage to germination was due to the occurrence of abnormal seedlings, with stunted and necrotic roots being the main anomaly found (Figure 3). According to Ferreira \& Áquila (2000), seedling growth is more sensitive to allelochemicals, because allelopathic substances cause the necrosis of the radicle and induce the appearance of abnormal seedlings. The phytochemical coumarin, present in the aqueous extract of L. camara leaves (Yi et al. 2006), causes necrosis and inhibition of root growth (Kupidlowska et al. 1994).

Other authors also reported that $L$. camara extracts negatively affected the twinning of seeds of several other species (Gorla \& Perez 1997, Hossain \& Alam 2010, Maiti et al. 2010, Mishra \& Singh 2010, Hussain et al. 2011, Kenany \& Darier 2013, Manohar et al. 2017).

A seedling growth inhibition of $B$. pilosa was observed when exposed to the L. camara extract. The root growth was highly affected, in comparison to the hypocotyl. Hypocotyl inhibition was observed in the LAG population and root growth reduction in the two populations, during the phases I and II. During the phase III, the leaf extract reduced the root size, when compared to the control treatment, by $49 \%$, $46 \%, 51 \%$ and $44 \%$ in the LAG and by $46 \%, 36 \%$, $38 \%$ and $55 \%$ in the SMA populations, respectively. When the seeds were exposed to the leaf extract at all phases (I, II and III), they presented an inhibition in seedling growth (hypocotyl and root growth) while the concentration was increased in both populations. When using $5 \%$ of leaf extract concentration, the hypocotyl and the radicle were reduced by $26 \%$ and $45 \%$ in the LAG and by $24 \%$ and $47 \%$ in the SMA populations, respectively (Figure 4).

The growth of seedlings depends on DNA synthesis, mitotic divisions and mobilization of seed-reserve substances (Cardoso 2004, Bewley et al. 2013), which, when inhibited by the action

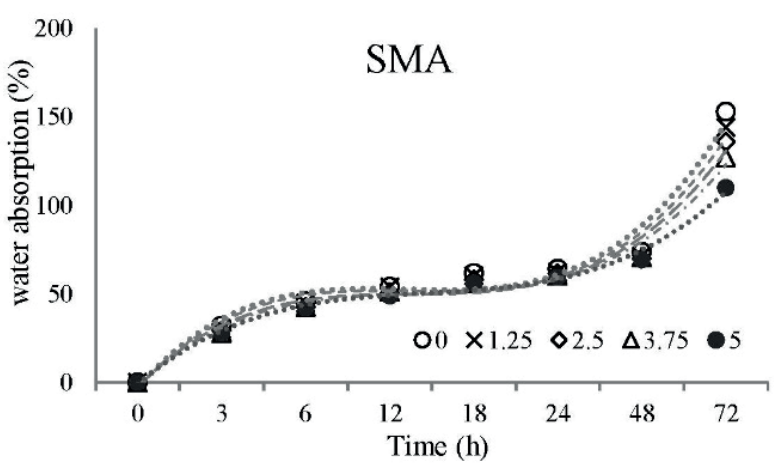

Figure 2. Bidens pilosa seeds submitted to aqueous extract concentrations of $0 \%, 1.25 \%, 2.5 \%, 3.75 \%$ and $5 \%$ (v/v) of Lantana camara leaves. LAG (Lages) and SMA (Santa Maria) are different plant populations from which the seeds were collected. The data represent the means of two independent experiments, with four replicates each $(n=2 \times 4)$. 

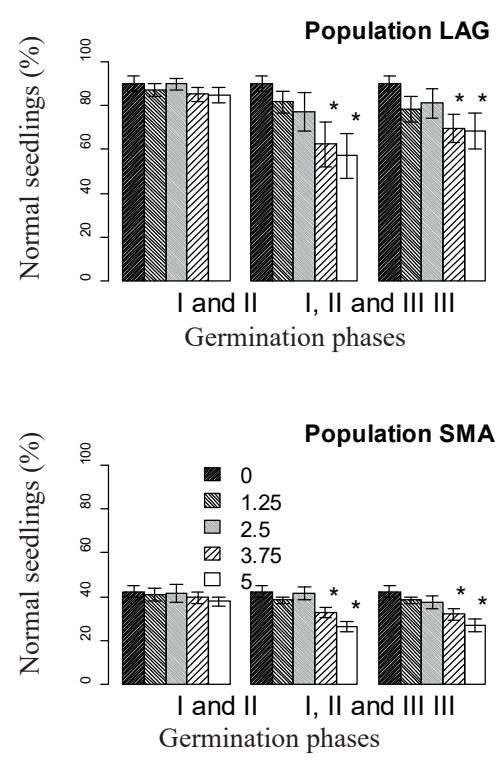
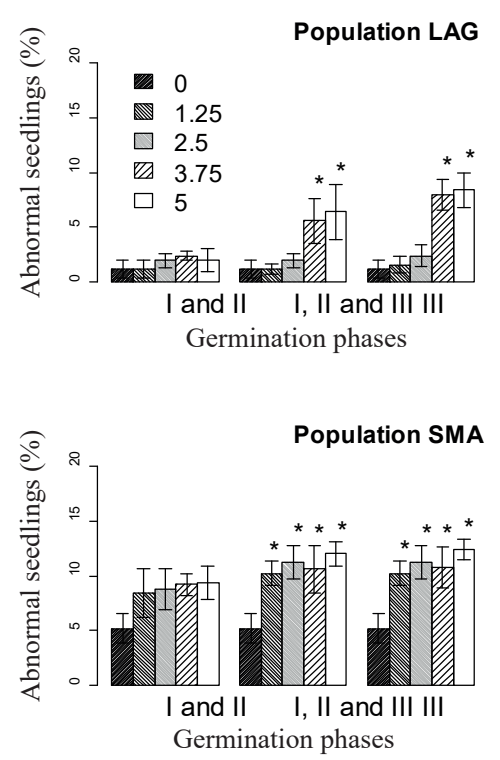

Population LAG
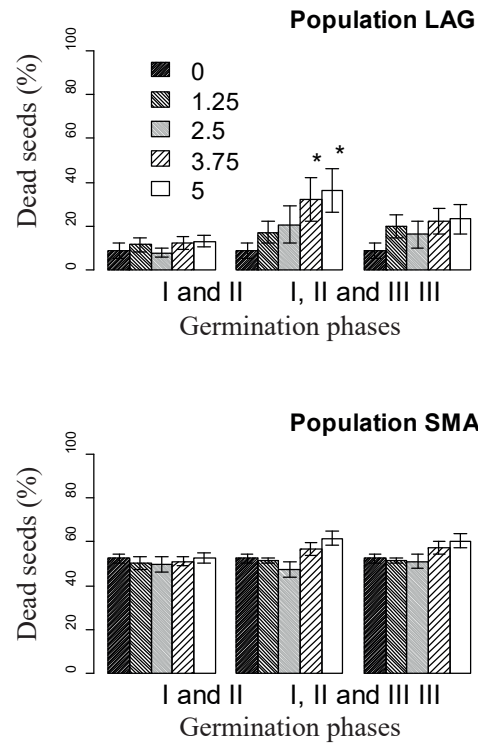

Figure 3. Effect of the extract concentrations $0 \%, 1.25 \%, 2.5 \%, 3.75 \%$ and $5 \%$ (v/v) of Lantana camara on Bidens pilosa seedling growth. The data represent the means and standard deviation of two independent experiments, with four replicates each $(\mathrm{n}=2 \times 4)$. Statistical significance was determined by Anova, with the Dunnett test $(* \mathrm{p}<0.05)$. LAG (Lages) and SMA (Santa Maria) are different plant populations from which the seeds were collected.
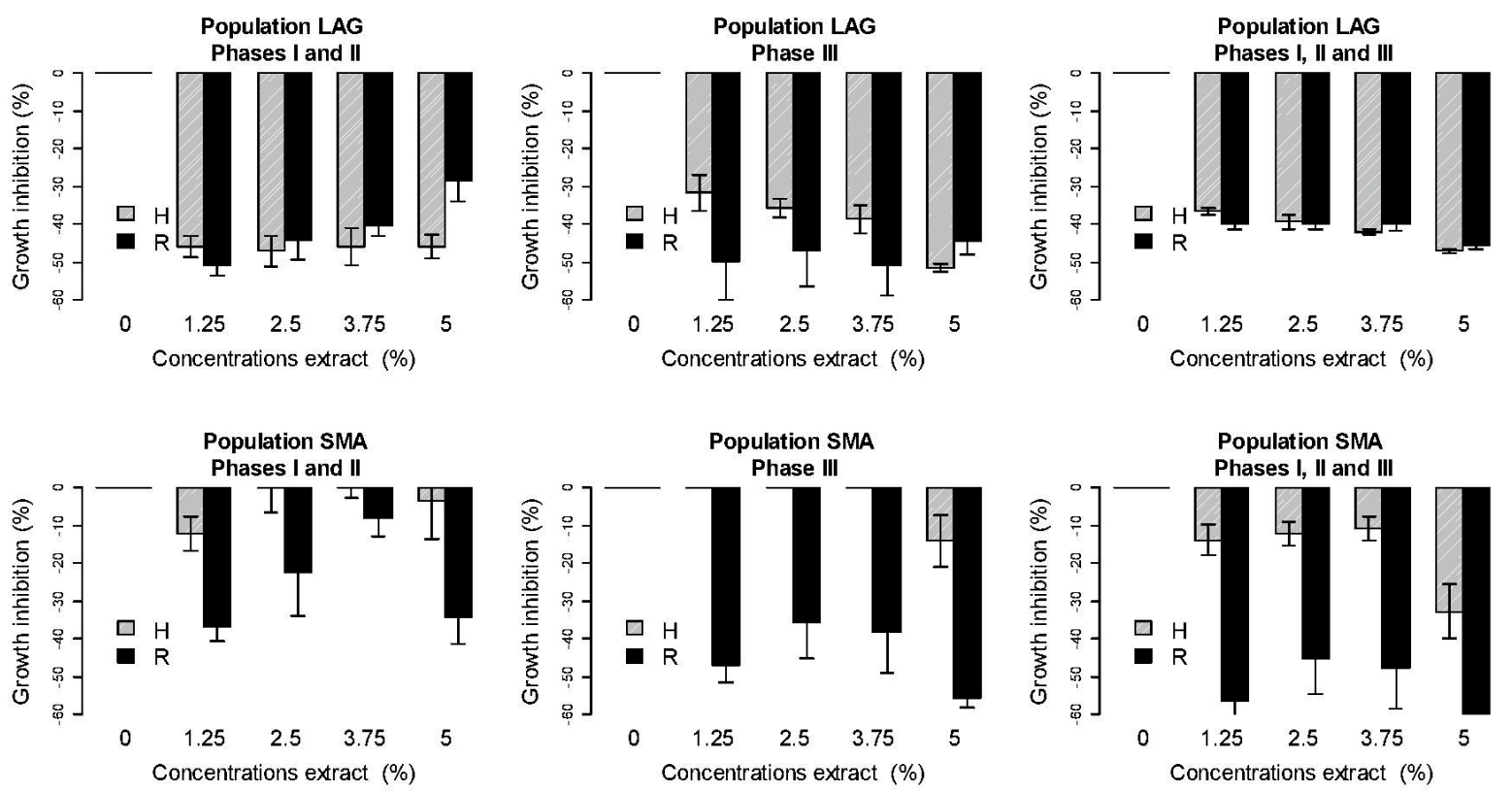

Figure 4. Effect of the extract concentrations $0 \%, 1.25 \%, 2.5 \%, 3.75 \%$ and $5 \%(\mathrm{v} / \mathrm{v})$ of Lantana camara on the inhibition of epicotyl $(\mathrm{H})$ and root $(\mathrm{R})$ growth of Bidens pilosa seedlings, during the germination phases I and II, III and I, and II and III. The data represent the means and standard deviation of two independent experiments, with four replicates each $(\mathrm{n}=2 \times 4)$. Statistical significance was determined by Anova, with the Dunnett test $(* \mathrm{p}<0.05)$. LAG (Lages) and SMA (Santa Maria) are different plant populations from which the seeds were collected.

of allelochemicals, compromise their normal development. Other authors also correlated a drastic reduction of the mitotic index to the cytotoxic effect in the root tip cells, with morphological modifications and necrosis caused by allelochemicals (Ladhari et al. 2014). The $L$. camara extract was also regarded 
to inhibit the root and stem elongation in many species, such as Brassica juncea L., Raphanus sativus L., Cucumis sativus L., Cicer arietinum L., Vigna mungo (L.) Hepper. and Vigna unguiculata (L.) Walp. (Ahmed et al. 2007); Parthenium hysterophorus L. (Mishra \& Singh 2010); Phalaris minor Retz and Sorghum bicolor (L.) Moench. (Kenany \& Darier 2013); Albizia lebbeck L. and Dalbergia sissoo Roxb. (Manohar et al. 2017).

The 1,8-cineol compound, present in L. camara leaves, has been also reported to be a reducer of mitotic index and root growth (Romagni et al. 2000). The vanillic and gallic acids present in L. camara leaves (Yi et al. 2006, Sousa et al. 2015) were suggested to have a role in the reduction of germination and seedling growth of $B$. pilosa (Moraes 2010).

A significant reduction of secondary roots was observed in seedlings exposed to the extract. The results of the presence of secondary roots were 31.6, 13.2, 8.4, 2.4 and 2.4 for the LAG and 12.4, 5.2, $2.8,0$ and 0.8 for the SMA populations, respectively (Figure 4). Ahmed et al. (2007) also observed a secondary inhibition of roots in B. juncea, R. sativus, $C$. sativus, $C$. arietinum, V. mungo and $V$. unguiculata, when exposed to L. camara aqueous extract during seed germination. Caspersen et al. (1999) noted that the secondary metabolite ferulic acid caused the absence of root hair in lettuce seedlings. The auxins are compounds characterized to mediate tropism responses, for their physiological activity in promoting the development of lateral roots (Bewley et al. 2013). The reduction or absence of secondary roots in the seedlings exposed to the allelochemicals may indicate changes in the metabolism of auxins caused by the allelopathic compounds present in the aqueous extract of $L$. camara leaves.

The seedlings submitted to the extract showed a discoloration of the hypocotyl, in relation to the control seedlings (Figure 5). Anthocyanins and carotenoids are pigments dissolved in vacuoles of epidermal tissues with antioxidant properties, responsible for the scavenging of the singlet oxygen (Abe et al. 2007). Other authors also reported a reduction in the content of carotenoid pigments in seedlings exposed to allelochemical extracts (Pandey et al. 2005, Ibrahim et al. 2013, Hussain et al. 2017), indicating that these may be involved in the process of defending seedlings from toxic compounds.

The $L$. camara extract caused a reduction in the germination speed index of seeds during the

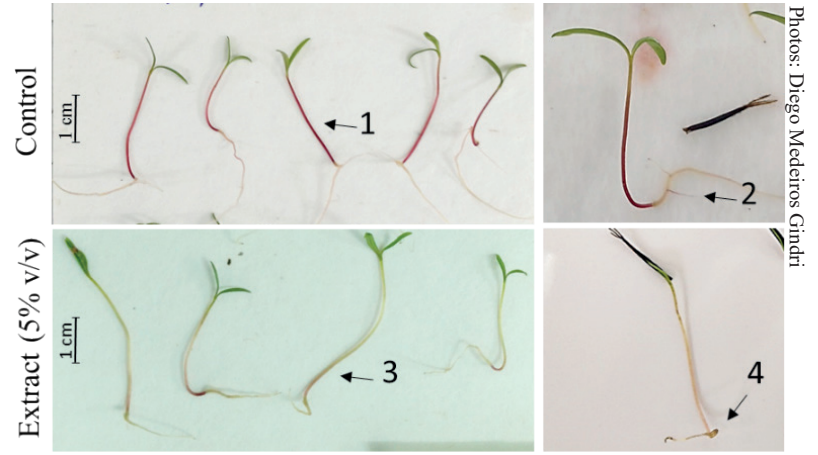

Figure 5. Effect of aqueous extract of Lantana camara leaves on seedlings of Bidens pilosa during germination. 1) Red hypocotyl; 2) secondary roots; 3) uncolored hypocotyl; 4) abnormal roots.

germination phases I and II at all concentrations tested in both populations, decreasing from 20.08 to 11.51 for the LAG and from 15.02 to 6.9 for the SMA populations (Figure 6). The observed delay in the radicle emission may be explained due to the growth interference of the allelochemicals present in the extract, such as reactivation of the mitochondrial cycle, oxidative phosphorylation, as well as the protein synthesis from substrates (enzymes, ribosomes, mRNA, etc.) that occur during the germination phases I and II (Cardoso 2004, Bewley et al. 2013). The results corroborate those previously reported by Gorla \& Perez (1997), who found that the L. camara aqueous extract affects the germination speed index of Lycopersicon esculentum and Cucumis sativus (Gorla \& Perez 1997). A reduction in the germination speed index of $B$. pilosa was also reported by Hoffmann et al. (2007), due to the action of Dieffenbachia picta Schott aqueous extracts.

One of the indicators of plasma membrane damage is the measurement of electrolyte leakage. The results showed a solute extravasation from the seeds (both populations), when exposed to the extract in all tested concentrations during $3 \mathrm{~h}, 12 \mathrm{~h}$ and $24 \mathrm{~h}$. The solute extravasation increased with the increase of the extract concentration (Figure 7), what allows to state that there is damage to the cell membranes repair system during the seed imbibition caused by the allelochemicals present in the extract.

Previous reports have shown that the increase of electrolyte flow may be one of the consequences of membrane integrity damage (Poonpaiboonpipat et al. 2013). Reigosa et al. (2001) also reported that the application of extract containing allelochemicals 

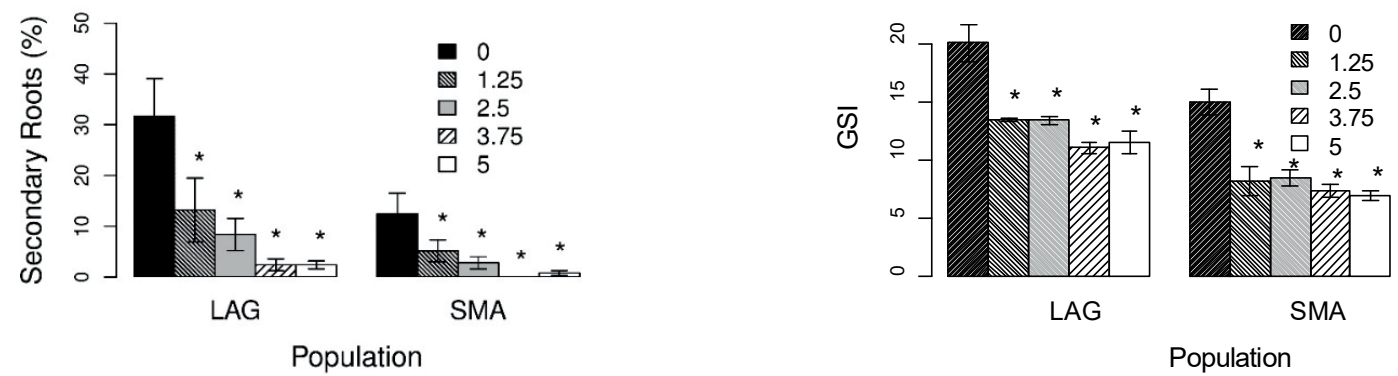

Figure 6. Effect of the extract concentrations $0 \%, 1.25 \%, 2.5 \%, 3.75 \%$ and $5 \%(\mathrm{v} / \mathrm{v})$ of Lantana camara on the secondary root growth and germination speed index (GSI) of Bidens pilosa. The data represent the means and standard deviation of two independent experiments, with four replicates each $(n=2 \times 4)$. The statistical significance was determined by Anova, with the Dunnett test $(* p<0.05)$. LAG (Lages) and SMA (Santa Maria) are different plant populations from which the seeds were collected.
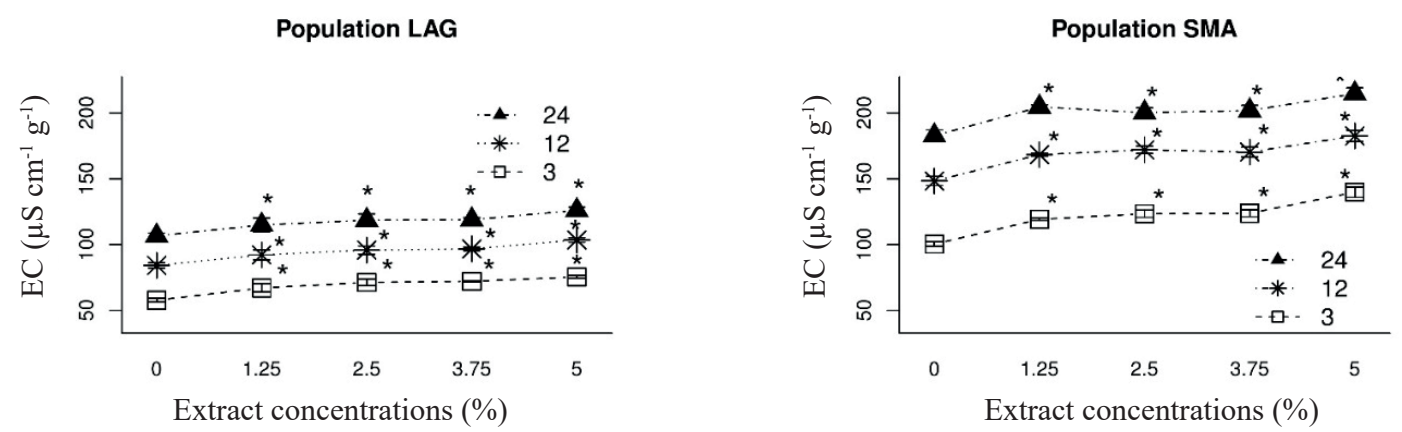

Figure 7. Effect of the extract concentrations $0 \%, 1.25 \%, 2.5 \%, 3.75 \%$ and $5 \%(\mathrm{v} / \mathrm{v})$ of Lantana camara leaves on the electrical conductivity (EC) of Bidens pilosa seeds. The data represent the means and standard deviation of two independent experiments, with four replicates each $(n=2 \times 4)$. The statistical significance was determined by Anova, with the Dunnett Test $\left({ }^{*} \mathrm{p}<0.05\right)$. LAG (Lages) and SMA (Santa Maria) are different plant populations from which the seeds were collected.

increases the leakage of electrolytes. Aumonde et al. (2013) also reported a higher release of lettuce seed electrolytes with increased concentrations of Philodendron bipinnatifidum aqueous extract.

Allelochemicals may damage cell membranes by directly interfering with a membrane component, or may result in alteration of some metabolic processes necessary to maintain the membrane functions (Bogatek \& Gniazdowska 2007). They can rapidly depolarize the cell membrane, increasing the permeability and inducing lipid peroxidation (Zeng et al. 2001, Yu et al. 2003). The benzoic acid, a metabolite found in L. camara leaves, has been argued to have an effect on the membranes, being able to cause changes in the polarity, what would bring changes to their structure and permeability (Yi et al. 2006, Mishra 2015).

Quinones and phenols (i.e., a group of allelochemical compounds), for example, are thought to have a toxic effect, due to their ability to form semiquinone radicals that donate electrons to molecular oxygen, forming reactive oxygen species (Testa 1995, Hammond-Kosak \& Jones 1996), which, in turn, may affect the membrane permeability, damage the DNA and proteins, and generate a lipid peroxidation signaling molecules (Weier et al. 2004), resulting in the formation of several byproducts, including MDA (Maness et al. 1999).

For the Fourier Transformed Infrared spectroscopy (ATR-FTIR), the FTIR spectra of the leaf powder and aqueous leaf extract presented 12 and 14 bands, respectively. In summary, monoterpenes (i.e., 1,8-cineole), bicyclic sesquiterpenes (i.e., $\beta$-caryophyllene), fragrant oils (terpenes, i.e., $\beta$-pinene), triterpenes (i.e., lantadene), phenolics (i.e., 2,4-dihydroxybenzoic acid derivatives) and flavonoids, esters and conjugated esters, carboxylic acids, ketones, alkenes and alcohols were the main compounds identified (Table 1).

Lantadene exhibits a vibration of the -OH group in the $3,448 \mathrm{~cm}^{-1}$ band, asymmetric stretching 
Table 1. Peaks found by ATR-FTIR spectra of leaf powder and aqueous leaf extract of Lantana camara and possible chemical group related.

\begin{tabular}{|c|c|c|}
\hline & Wave $\mathrm{n}^{\mathrm{o}}\left(\mathrm{cm}^{-1}\right)$ & Assignment \\
\hline \multirow{12}{*}{ 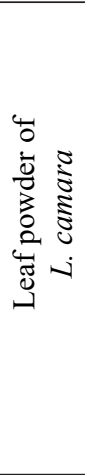 } & 1063 & $\mathrm{C}-\mathrm{O}$ of ester groups or $\mathrm{C}-\mathrm{C}$ and $\mathrm{C}-\mathrm{O}-\mathrm{C}$ vibration in 1,8 -cineole ${ }^{1 ; 2 ; 5}$ \\
\hline & 1154 & Unknown \\
\hline & 1201 & C-O; C-O-H; C-C; and C-N amines or C-C-O group of phenolics $5 ; 1 ; 2 ; 4$ \\
\hline & 1265 & C-O vibration of hydroxyl flavonoids or C-C-O group of phenolics ${ }^{5 ; 1}$ \\
\hline & 1420 & COO- vibration ${ }^{1}$ \\
\hline & 1444 & $\mathrm{CH}_{2}$ group in $\beta$-caryophyllene ${ }^{1}$ \\
\hline & 1518 & $\mathrm{C}=\mathrm{C}$ vibrations aromatic rings of phenolics and flavonoids ${ }^{5}$ \\
\hline & 1609 & $\mathrm{C}=\mathrm{O}$ of ketones or conjugated alkenes; $-\mathrm{COOH}$ of esters ${ }^{4 ; 1}$ \\
\hline & 1640 & $\beta$ - pinene $C=C$ ring vibration and $\beta$-caryophyllene asymmetric bending vibration of amine $\mathrm{N}-\mathrm{H}^{1 ; 5}$ \\
\hline & 2927 & $\mathrm{CH}_{3}$ or $-\mathrm{CH}_{2}$ vibration in carboxylic acids ${ }^{2 ; 5}$ \\
\hline & 3388 & Hydroxyl groups attached to alcohol and carboxylic acid $4 ; 5$ \\
\hline & 3396 & Hydroxyl groups attached to alcohol and carboxylic acid ${ }^{4 ; 5}$ \\
\hline \multirow{9}{*}{ 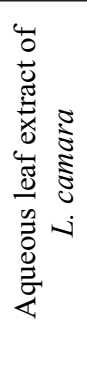 } & 979 & C-O; C-O-H; C-C; C-O-C vibrations in 1,8-cineole and Lantadene ${ }^{2 ; 5 ; 3}$ \\
\hline & 1006 & C-O; C-O-H; C-C; C-O-C vibrations in 1,8-cineole and Lantadene ${ }^{2 ; 5 ; 3}$ \\
\hline & 1365 & $\mathrm{CH}_{3}(\mathrm{C}=\mathrm{O})$ of ester groups in 1,8-cineole and $ß$-caryophyllene $\mathrm{e}^{1 ; 2 ; 5}$ \\
\hline & 1375 & $\mathrm{CH}_{3}(\mathrm{C}=\mathrm{O})$ of ester groups \\
\hline & 1397 & $\mathrm{CH}_{3}(\mathrm{C}=\mathrm{O})$ of ester groups in 1,8-cineole and $\beta$-caryophyllene $\mathrm{e}^{1 ; 2 ; 5}$ \\
\hline & 1436 & $\mathrm{CH}_{2}$ vibration in Lantadene ${ }^{1}$ \\
\hline & 1458 & $\mathrm{C}-\mathrm{H} ; \mathrm{CH}_{3} ; \mathrm{CH}_{2} ;$ and $\mathrm{C}=\mathrm{C}$ aromatic rings flavonoids and phenolics ${ }^{1 ; 5}$ \\
\hline & 1473 & Deformation of $\mathrm{C}-\mathrm{H}$ in $-\mathrm{CH}_{2}{ }^{2}$ \\
\hline & $\begin{array}{l}1978 ; 2621 ; 3841 \\
3867 ; 3902 ; 3920\end{array}$ & Unknown \\
\hline
\end{tabular}

${ }^{1}$ Schulz \& Baranska (2007); ${ }^{2}$ Lu \& Rasco (2012); ${ }^{3}$ Ingawale \& Goswami-Giri (2014); ${ }^{4}$ Kumar et al. (2015); ${ }^{5}$ Oliveira et al. (2016).

of $\mathrm{CH},-\mathrm{CH}_{3}$ or $-\mathrm{CH}_{2}$ groups in carboxylic acids in the $2,921 \mathrm{~cm}^{-1}$ band, group vibration $-\mathrm{CH}_{2}$ at $1,455 \mathrm{~cm}^{-1}$ and elongation of the $\mathrm{CCO}$ group in the $1,303 \mathrm{~cm}^{-1}$ band (Ingawale \& Goswami-Giri 2014). These vibrational signatures were found in L. camara leaves, in bands of $3,396 \mathrm{~cm}^{-1}, 2,927 \mathrm{~cm}^{-1}, 1,444 \mathrm{~cm}^{-1}$ and $1,265 \mathrm{~cm}^{-1}$, evidencing the presence of Lantadene. The derivative of salicylic acid 2,4-dihydroxybenzoic acid exhibits a vibration of the $-\mathrm{OH}$ group in the $3,374 \mathrm{~cm}^{-1}$ band and the $\mathrm{C}=\mathrm{O}$ group in the $1,650 \mathrm{~cm}^{-1}$ band (Takac \& Topic 2004). The salicylic acid and its 2,4-dihydroxy derivative are present in many plants, being also found in L. camara leaves.

The 1,8-cineol compound has been cited as an important intermediate source for the preparation of herbicides, since cineole has significant phytotoxic properties (Lana et al. 2006, Kegge \& Pierik 2009). According to Baetz \& Martinoia (2014), 1,8-cineole is released from the roots of Arabidopsis during the interaction with pathogens, presenting percutaneous penetration and also decongestants, antitussives, analgesics, anti-inflammatory and hepatoprotective effects (Lima et al. 2013). $\beta$-caryophyllene presents a low toxicity and high applicability. The compound showed protective and therapeutic effects in preclinical studies (Loreto \& Schnitzler 2010, Stenberg et al. 2015, Yoo \& Jwa 2018). Pinene is reported as having an adaptive protection against predators, with antimicrobial, anti-inflammatory and bronchodilator activity (Holopainen 2004).

For the high performance liquid chromatography coupled with mass spectrometry (HPLC-MS) of the leaf extract, the possible compounds found in the L. camara extract by the spectrometric technique in a positive mode were salicylic acid [retention time 0.659, Mass 138.0316, $139.039 \mathrm{~m} / \mathrm{z}(-\mathrm{H})]$, camaraside [retention time 1.786, Mass 492.12691, $493.1351 \mathrm{~m} / \mathrm{z}(-\mathrm{H})]$ and camaroside [retention time 2.148, Mass 476.13224, 477.1405 m/z (-H)], while, in a negative mode, they were isoverbascoside, lantanaside and verbascoside [retention time 1.094, Mass 624.20614, $623.1986 \mathrm{~m} / \mathrm{z}(-\mathrm{H})]$, with identical molar mass and molecular formula $\left(\mathrm{C}_{29} \mathrm{H}_{36} \mathrm{O}_{15}\right)$, and lantadene A, lantadene D and 22 $\beta$-hidroxi-3oxoolean-12-en-28-oic acid [retention time 4.786, Mass 554.39856, $553.3913 \mathrm{~m} / \mathrm{z}(-\mathrm{H})]$, with identical molar mass and molecular formula $\left(\mathrm{C}_{35} \mathrm{H}_{54} \mathrm{O}_{5}\right)$.

Yi et al. (2006) reported that the salicylic acid polyphenol present in the L. camara leaf extract caused a strong inhibition in the growth 
and development of Eichhornia crassipes (Mart.) Solms. The allelopathic effect of salicylic acid is attributed to the inhibition of the absorption of $\mathrm{K}+$ and the depolarization of the membrane of the root cells (Glass \& Dunlop 1974, Harper \& Balke 1981). The camaraside compound was reported present in L. camara by Wahab (2004); however, it was not related to allelophatic effects. No reports of allelopathy caused by camaroside were found.

Isoverbascoside, lantanaside and verbascoside have already been reported in L. camara leaves (Herbert et al. 1991, Ghisalberti 2000, Sousa \& Costa 2012); however, none of them were reported to have allelophatic activity. Verbascoside was reported as an inhibitor of the protein kinase and antitumor processes (Herbert et al. 1991), and also has antibacterial activity (Pereira et al. 2008). Lantadene has the ability to inhibit the plant growth (Kong et al. 2006, Kong 2010) and antioxidant, cytotoxic, insecticidal and animal toxicity, due to hepatic insufficiency and other organs (Ghisalberti 2000, Litaudon et al. 2009, Grace-Lynn et al. 2012, Sousa \& Costa 2012).

The obtained results may not be conclusive, but may be an indicative of which compounds may be present in the tested extracts. The compounds identified by HPLC/MS were salicylic acid and lantadene. The salicylic acid compound presented assignments on the FT-IR spectra of the leaves; however, it was not found in the aqueous extract. Lantadene already presented vibrational bands on both the leaves and aqueous extract. Results prompt us to conclude that lantadene may be the metabolite present in the aqueous extract of L. camara leaves, what confers the allelopathy property during the germination of $B$. pilosa.

\section{CONCLUSION}

The Lantana camara leaf extract reduces the viability of Bidens pilosa seeds during the germination phase III, reduces the germination speed index in the phases I and II and causes solute extravasation, abnormalities in geotropism and root development. At 1.25-5.00\% concentrations, the extract inhibits the root and epicotyl growth, indenpendently of the sampled population. Lantane $\mathrm{A}$ and $\mathrm{B}$ are the possible compounds involved in phytotoxicity. The results prompt us to state that the L. camara extract has a potential to be used in the development of environmentally-friendly natural herbicides.

\section{ACKNOWLEDGMENTS}

The first author (D. M. Gindri) thanks the Companhia Integrada de Desenvolvimento Agrícola de Santa Catarina (CIDASC), for contibuting to do its Ph.D. in Crop Production, as well as the Universidade do Estado de Santa Catarina (UDESC) and the Seed Analysis Laboratory (LAS), for providing research facilities. Prof. C. M. M. Coelho thanks the $\mathrm{CNPq} / \mathrm{Capes}$, for research fellowships. V. G. Uarrota thanks the FONDECYT-CONICYT (Project number 3190055) and the Vicerrectoria de Investigacion y Estudios Avanzados of the Pontificia Universidade Católica de Valparaiso, for research facilities.

\section{REFERENCES}

ABE, L. T.; MOTA, R. V.; LAJOLO, F. M.; GENOVESE, M. I. Compostos fenólicos e capacidade antioxidante de cultivares de uvas Vitis labrusca L. e Vitis vinifera L. Ciência e Tecnologia de Alimentos, v. 27, n. 2, p. 394400, 2007.

ABU-ROMMAN, S.; SHATNAWI, M.; SHIBLI, R. Allelopathic effects of spurge (Euphorbia hierosolymitana) on wheat (Triticum durum). American Eurasian Journal of Agricultural \& Environmental Sciences, v. 7, n. 3, p. 298-302, 2010.

AHMED, R.; KHAM, M. A. S. A.; MUKUL, S. A.; HOSSAIN, M. K. Allelopathic effects of Lantana camara on germination and growth behavior of some agricultural crops in Bangladesh. Journal of Forestry Research, v. 18, n. 4, p. 301-304, 2007.

AUMONDE, T. Z.; MARTINAZZO, E. G.; PEDÓ, T.; BORELLA, J.; AMARANTE, L.; VILELLA, F. A.; MORAES, D. M. Respostas fisiológicas de sementes e plântulas de alface submetidas ao extrato de Philodendron bipinnatifidum. Semina: Ciências Agrárias, v. 34, n. 6, p. 3181-3192, 2013.

BAETZ, U.; MARTINOIA, E. Root exudates: the hidden part of plant defense. Trends in Plant Science, v. 19, n. 1, p. 90-98, 2014.

BEWLEY, J.; BRADFORD, K.; HILHORST, H.; NONOGAKI, H. Germination. In: BEWLEY, J.; BRADFORD, K.; HILHORST, H.; NONOGAKI, H. (ed.). Seeds: physiology of development, germination and dormancy. 3. ed. New York: Springer, 2013. p. 133182.

BOGATEK, R.; GNIAZDOWSKA, A. ROS and phytohormons in plant-plant allelopathic interaction. Plant Signaling \& Behavior, v. 2, n. 4, p. 317-318, 2007. 
CANTRELL, C. L.; DAYAN, F. E.; DUKE, S. O. Natural products as sources for new pesticides. Journal of Natural Products, v. 75, n. 6, p. 1231-1242, 2012.

CARDOSO, V. J. M. Germinação. In: KERBAUY, G. B. (ed.). Fisiologia vegetal. 2. ed. Rio de Janeiro: Guanabara Koogan, 2004. p. 386-407.

CASPERSEN, S.; SUNDIN, P.; MUNRO, M.; AĐALSTEINSSON, S.; HOOKER, J. E.; JENSEN, P. Interactive effects of lettuce (Lactuca sativa L.), irradiance, and ferulic acid in axenic, hydroponic culture. Plant and Soil, v. 210, n. 1, p. 115-126, 1999.

DAY, M. D.; WILEY, C. J.; PLAYFORD, J.; ZALUCKI, M. P. Lantana current management status and future prospects. Camberra: Australian Centre for International Agricultural Research, 2003.

FERREIRA, A. G.; ÁQUILA, M. E. A. Alelopatia: uma área emergente da ecofisiologia. Revista Brasileira de Fisiologia Vegetal, v. 12, n. esp., p. 175-204, 2000.

GHISALBERTI, E. L. Lantana camara L. (Verbenaceae). Fitoterapia, v. 71, n. 5, p. 467-486, 2000.

GLASS, A.; DUNLOP, J. Influence of phenolic acids on ion uptake: IV. Depolarization of membrane potentials. Plant Physiology, v. 54, n. 6, p. 855-858, 1974.

GORLA, C.; PEREZ, S. Influência de extratos aquosos de folhas de Miconia albicans Triana, Lantana camara L., Leucaena leucocephala (Lam) de Wit e Drimys winteri Forst, na germinação e crescimento inicial de sementes de tomate e pepino. Revista Brasileira de Sementes, v. 19, n. 2, p. 261-266, 1997.

GRACE-LYNN, C.; DARAH, I.; CHEN, Y.; LATHA, L. Y.; JOTHY, S. L.; SASIDHARAN S. In vitro antioxidant activity potential of Lantadene A, a pentacyclic triterpenoid of Lantana plants. Molecules, v. 17, n. 12, p. 11185-11198, 2012.

HAMMOND-KOSACK, K. E.; JONES, J. D. G. Resistance gene-dependent plant defense responses. The Plant Cell, v. 8, n. 10, p. 1773-1791, 1996.

HARPER, J.; BALKE, N. Characterization of the inhibition of $\mathrm{K}+$ absorption in oat roots by salicylic acid. Plant Physiology, v. 68, n. 6, p. 1349-1353, 1981.

HEAP, I. The international survey of herbicide resistant weeds. 2014. Disponível em: http://www.weedscience.org/ Account/AboutUs.aspx. Acesso em: 21 out. 2014.

HERBERT, J. M.; MAFFRAND, J. P.; TAOUBI, K.; AUGEREAU, J. M.; FOURASTE, I.; GLEYE, J. Verbascoside isolated from Lantana camara, an inhibitor of protein kinase C. Journal of Natural Products, v. 54, n. 6 , p. 1595-1600, 1991.

HOFFMANN, C. E. F.; NEVES, L. A. S.; BASTOS, C. F.; WALLAU, G. L. Atividade alelopática de Nerium Oleander L. e Dieffenbachia picta Schott em sementes de
Lactuca Sativa L. e Bidens pilosa L. Revista de Ciências Agroveterinárias, v. 6, n. 1, p. 11-21, 2007.

HOLOPAINEN, J. K. Multiple functions of inducible plant volatiles. Trends in Plant Science, v. 9, n. 11, p. 529-533, 2004.

HOSSAIN, M. K.; ALAM, N. M. D. Allelopathic effects of Lantana camara leaf extract on germination and growth behavior of some agricultural and forest crops in Bangladesh. Pakistan Journal of Weed Science Research, v. 16, n. 2, p. 217-226, 2010.

HUSSAIN, F.; GHULAM, S.; SHER, Z.; AHMAD, B. Allelopathy by Lantana camara. Pakistan Journal of Botany, v. 43, n. 5, p. 2373-2378, 2011.

HUSSAIN, I.; SINGH, N. B.; SINGH, A.; SINGH, H. Allelopathic potential of sesame plant leachate against Cyperus rotundus L. Annals of Agrarian Science, v. 15, n. 1, p. 141-147, 2017.

HUSSAIN, M.; REIGOSA, M. Allelochemical stress inhibits growth, leaf water relations, PSII photochemistry, non-photochemical fluorescence quenching, and heat energy dissipation in three $\mathrm{C} 3$ perennial species. Journal of Experimental Botany, v. 62, n. 13, p. 4533-4545, 2011.

IBRAHIM, M.; AHMAD, N.; SHINWARI, Z. K.; BANO, A.; ULLAH, F. Allelopathic assessment of genetically modified and non-modified maize (Zea mays L.) on physiology of wheat (Triticum aestivum L.). Pakistan Journal of Botany, v. 45, n. 13, p. 235-240, 2013.

INGAWALE, G.; GOSWAMI-GIRI, A. Isolation and characterization of bioactive molecule from Lantana camara. Asian Journal Research Chemistry, v. 7, n. 3, p. 339-344, 2014.

KEGGE, W.; PIERIK, R. Biogenic volatile organic compounds and plant competition. Trends in Plant Science, v. 15 , n. 3 , p. 126-132, 2010.

KENANY, E.; DARIER, S. Suppression effects of Lantana camara L. aqueous extracts on germination efficiency of Phalaris minor Retz. and Sorghum bicolor L. (Moench). Journal of Taibah University for Science, v. 7, n. 2, p. 64$71,2013$.

KOHLI, R. K.; BATISH, D.; SINGH, H. P. Allelopathy and its implications in agroecosystems. Journal of Crop Production, v. 1, n. 1, p. 169-202, 1997.

KONG, C. H.; WANG, P.; ZHANG, C. X.; ZHANG, M. X.; HU, F. Herbicidal potential of allelochemicals from Lantana camara against Eichhornia crassipes and the alga Microcystis aeruginosa. Weed Research, v. 46, n. 4, p. 290-295, 2006.

$\mathrm{KONG}, \mathrm{C}$. H. Ecological pest management and control by using allelopathic weeds (Ageratum conyzoides, Ambrosia trifida, and Lantana camara) and their allelochemicals in China. Weed Biology and Management, v. 10, n. 1, p. 73-80, 2010. 
KUMAR, S. S.; MANOJ, P.; GIRIDHAR, P. Fourier transform infrared spectroscopy (FTIR) analysis, chlorophyll content and antioxidant properties of native and defatted foliage of green leafy vegetables. Journal of Food Science and Technology, v. 52, n. 12, p. 8131-8139, 2015.

KUPIDLOWSKA, E.; DOBRZYNSKA, K.; PARYS, E.; ZOBEL, A. M. Effect of coumarin and xanthotoxin on mitochondrial structure, oxygen uptake, and succinate dehydrogenase activity in onion root cells. Journal of Chemical Ecology, v. 20, n. 10, p. 2471-2480, 1994.

LADHARI, A.; OMEZZINE, F.; HAOUALA, R. The impact of Tunisian Capparidaceae species on cytological, physiological and biochemical mechanisms in lettuce. South African Journal of Botany, v. 93, n. 1, p. 222-230, 2014.

LANA, E. J. L.; ROCHA, K. A. S.; KOZHEVNIKOV, I. V.; GUSEVSKAYA, E. V. Synthesis of 1,8-cineole and 1,4 -cineole by isomerization of $\alpha$-terpineol catalyzed by heteropoly acid. Journal of Molecular Catalysis A: Chemical, v. 259, n. 1-2, p. 99-102, 2006.

LATIF, S.; CHIAPUSIO, G.; WESTON, L. A. Allelopathy and the role of allelochemicals in plant defense. In: BECARD, G. (ed.). Advances in Botanical Research. Wagga Wagga: Academic Press, 2017. p. 19-54.

LIMA, H. R. P.; OLIVEIRA, S. C. C.; IKEDA, F. S.; MORAES, L. F. D. Alelopatia: potencialidades do seu uso no controle do mato. In: OLIVEIRA, M. F.; BRIGHENTI, A. M. (ed.). Controle de plantas daninhas: métodos físico, mecânico, cultural, biológico e alelopatia. Brasília, DF: Embrapa, 2018. p. 148-164.

LIMA, P. R.; MELO, T. S.; CARVALHO, K. M.; OLIVEIRA, Í. B.; ARRUDA, B. R.; BRITO, G. A. C.; RAO, V. S.; SANTOS, F. A. 1,8-cineole (eucalyptol) ameliorates cerulein-induced acute pancreatitis via modulation of cytokines, oxidative stress and NF- $\kappa \mathrm{B}$ activity in mice. Life Sciences, v. 92, n. 24-26, p. $1195-$ 1201, 2013.

LITAUDON, M.; JOLLY, C.; LE CALLONEC, C.; CUONG, D. D.; RETAILlEAU, P.; NOSJEAN, Ó.; NGUYEN, V. H.; PFEIFFER, B.; BOUTIN, J. A.; GUÉRITTE, F. Cytotoxic pentacyclic triterpenoids from Combretum sundaicum and Lantana camara as inhibitors of Bcl-xL/BakBH3 domain peptide interaction. Journal of Natural Products, v. 72, n. 7, p. 1314-1320, 2009.

LORENZI, H. Plantas daninhas do Brasil. 7. ed. Nova Odessa: Instituto Plantarum de Estudos da Flora, 2014.

LORETO, F.; SCHNIZLER, J. Abiotic stresses and induced BVOCs. Trends in Plant Science, v. 15, n. 3, p. 154-166, 2010.

LU, X.; RASCO, B. Determination of antioxidant content and antioxidant activity in foods using infrared spectroscopy and chemometrics: a review. Critical Reviews in Food Science and Nutrition, v. 52, n. 10, p. 853-875, 2012.

MAITI, P. P.; BHAKAT, R. K.; BHATTACHARJEE, A. Evalution of allelopathic potential of an obnoxious weed using mung bean as a bioassay material. International Journal of Science and Nature, v. 1, n. 2, p. 236-241, 2010.

MANESS, P. C.; SMOLINSKI, S.; BLAKE, D. M.; HUANG, Z.; WOLFRUM, E. J.; JACOBY, W. A. Bactericidal activity of photocatalytic $\mathrm{TiO} 2$ reaction: toward an understanding of its killing mechanism. Applied and Environmental Microbiology, v. 65, n. 9, p. 40944098, 1999.

MANOHAR, K.; KHARE, N.; KUMAR, H. Effects of leaf extract of Lantana camara on germination and growth behavior of selected tree species. International Journal of Current Microbiology and Applied Sciences, v. 6, n. 7, p. 2519-2526, 2017.

MISHRA, A. Allelopathic properties of Lantana camara. International Research Journal of Basic and Clinical Studies, v. 3, n. 1, p. 13-28, 2015.

MISHRA, A.; SINGH, R. Comparative study of effect of Lantana camara extract of different parts on seed germination of Parthenium hysterophorus L. International Journal of Plant Sciences, v. 5, n. 1, p. 74-75, 2010.

MORAES, P. V. D. Potencial alelopático de extratos aquosos de mourisco (Fogopyrum esculentum Moench) na germinação e crescimento inicial de plantas daninhas. Revista Trópica: Ciências Agrárias e Biológicas, v. 4, n. 3, p. 10-16, 2010.

NAKAGAWA, J. Testes de vigor baseados no desempenho de plântulas. In: KRZYZANOWSKI, F. C.; VIEIRA, R. D.; FRANÇA NETO, J. B. (ed.). Vigor de sementes: conceitos e testes. 2 ed. Londrina: Abrates, 1999. p. 1-24.

OLIVEIRA, R. N.; MANCINI, M. C.; OLIVEIRA, F. C. S.; PASSOS, T. M.; QUILTY, B.; THIRÉ, R. M. S. M.; MCGUINNESS, G. B. FTIR analysis and quantification of phenols and flavonoids of five commercially available plants extracts used in wound healing. Matéria, v. 21, n. 3, p. 767-779, 2016.

PANDEY, D.; MISHRA, N.; SINGH, P. Relative phytotoxicity of hydroquinone on rice (Oryza sativa L.) and associated aquatic weed green musk chara (Chara zeylanica Willd.). Pesticide Biochemistry and Physiology, v. 83, n. 2-3, p. 82-96, 2005.

PEREIRA, A. C.; CARVAlho, H. W. P.; SIlVA, G. H.; OLIVEIRA, D. F.; FIGUEIREDO, H. C. P.; CAVALHEIRO, A. J.; CARVALHO, D. A. Purification of an antibacterial compound from Lantana lilacina. Revista Brasileira de Farmacognosia, v. 18, n. 2, p. 204-208, 2008.

POONPAIBOONPIPAT, T.; PANGNAKORN, U.; SUVUNNAMEK, U.; TEERARAK, M.; 
CHAROENYING, P.; LAOSINWATTANA, C. Phytotoxic effects of essential oil from Cymbopogon citratus and its physiological mechanisms on barnyardgrass (Echinochloa crus-galli). Industrial Crops and Products, v. 41, n. 1, p. 403-407, 2013.

QIAN, H.; XU, X.; CHEN, W.; JIANG, H.; JIN, Y.; LIU, W.; FU, Z. Allelochemical stress causes oxidative damage and inhibition of photosynthesis in Chlorella vulgaris. Chemosphere, v. 75, n. 3, p. 368-375, 2009.

R CORE TEAM. $R$ : a language and environment for statistical computing. Vienna: R Foundation for Statistical Computing, 2017.

REIGOSA, M.; GOMES, A.; FERREIRA, A.; BORGHETTI, F. Allelopathic research in Brazil. Acta Botanica Brasilica, v. 27, n. 4, p. 629-646, 2013.

REIGOSA, M. J.; GONZALEZ, L.; SANCHESMOREIRAS, A.; DURAN, B.; PRUME, D.; FERNANDEZ, D. A.; BOLANO, J. C. Comparison of physiological effects of allelochemicals and commercial herbicides. Allelopathy Jounal, v. 8, n. 2, p. 211-220, 2001.

ROMAGNI, J. G.; ALlEN, S. N.; DAYAN, F. E. Allelopathic effects of volatile cineoles on two weedy plant species. Journal of Chemical Ecology, v. 26, n. 1, p. $303-313,2000$.

SCHULZ, H.; BARANSKA, M. Identification and quantification of valuable plant substances by IR and Raman spectroscopy. Vibrational Spectroscopy, v. 43, n. 1, p. 13-25, 2007.

SHARMA, O. P.; SHARMA, S.; PATTABHI, V.; MAHATO, S. B.; SHARMA, P. D. A review of the hepatotoxic plant Lantana camara. Critical Reviews in Toxicology, v. 37, n. 4, p. 313-352, 2007.

SHARMA, O. P.; MAKKAR, H. P.; PAL, R. N.; NEGI, S. S. Lantadene: a content and toxicity of the Lantana plant (Lantana camara, Link.) to guinea pigs. Toxicon, v. 18, n. 4 , p. 485-488, 1980.

SHARMA, O. P.; DAWRA, R. K.; RAMESH, D. A triterpenoid acid, Lantadene D from Lantana camara var. Aculeata. Phytochemistry, v. 29, n. 12, p. 3961-3962, 1990.

SOUSA, E. O.; MIRANDA, C. M. B. A.; NOBRE, C. B.; BOLIGON, A. A.; ATHAYDE, M. L.; COSTA, J. G. M. Phytochemical analysis and antioxidant activities of Lantana camara and Lantana montevidensis extracts. Industrial Crops and Products, v. 70, n. 1, p. 7-15, 2015.

SOUSA, E.; COSTA, J. Genus Lantana: chemical aspects and biological activities. Revista Brasileira de Farmacognosia, v. 22, n. 5, p. 1115-1180, 2012.

SOUZA FILHO, A.; GUILHON G.; SANTOS, L. Metodologias empregadas em estudos de avaliação da atividade alelopática em condições de laboratório. Planta Daninha, v. 28, n. 3, p. 689-697, 2010.

STENBERG, J. A.; HEIL, M.; AHMAN, I.; BJÖRKMAN, C. Optimizing crops for biocontrol of pests and disease. Trends in Plant Science, v. 20, n. 11, p. 698-712, 2015.

TAKAC, M.; TOPIC, D. FT-IR and NMR spectroscopic studies of salicylic acid derivatives: II. Comparison of 2-hydroxy- and 2,4- and 2,5-dihydroxy derivatives. Acta Pharmaceutica, v. 54, n. 3, p. 177-191, 2004.

TESTA, B. The metabolism of drugs and other xenobiotics. New York: Academic Press, 1995.

UARROTA, V.; AMANTE, E.; DEMIATE, I.; VIEIRA, F.; DELGADILLO, I; MARASCHIN, M. Physicochemical, thermal, and pasting properties of flours and starches of eight Brazilian maize landraces (Zea mays L.). Food Hydrocolloids, v. 30, n. 2, p. 614-624, 2013.

VERDEGUER, M.; BLÁZQUEZ, M.; BOIRA, H. Phytotoxic effects of Lantana camara, Eucalyptus camaldulensis and Eriocephalus africanus: essential oils in weeds of Mediterranean summer crops. Biochemical Systematics and Ecology, v. 37, n. 4, p. 362-369, 2009.

VIEIRA, R. D; CARVALHO, N. M. Testes de vigor em sementes. Jaboticabal: Funep, 1994.

WAHAB, A. Studies on the chemical constituents of Lantana camara L. 2004. Thesis - University of Karachi, Pakistan, 2004.

WANG, C.; ZHU, M.; CHEN, X; BO, Q. Review on allelopathy of exotic invasive plants. Procedia Engineering, v. 18, n. 1, p. 240-246, 2011.

WEIR, T.; PARK, S.; VIVANCO, J. Biochemical and physiological mechanisms mediated by allelochemicals. Current Opinion in Plant Biology, v. 7, n. 4, p. 472-479, 2004.

YI, Z.; ZHANG, M.; LING, B.; XU, D.; YE, J. Inhibitory effects of Lantana camara and its contained phenolic compounds in Eichhornia crassipes growth. Journal of Applied Ecology, v. 17, n. 9, p. 1637-1640, 2006.

YOO, H.; JWA, S. Inhibitory effects of $\beta$-caryophyllene on Streptococcus mutans biofilm. Archives of Oral Biology, v. 88, n. 1, p. 42-46, 2018.

YU, J.; YE, S.; ZHANG, M.; HU, W. Effects of root exudates and aqueous root extracts of cucumber (Cucumis sativus) and allelochemicals, on photosynthesis and antioxidant enzymes in cucumber. Biochemical Systematics and Ecology, v. 31, n. 2, p. 129-139, 2003.

ZENG, R. S.; LUO, S. M.; SHI, Y. H.; SHI, M. B.; TU, C. Y. Physiological and biochemical mechanism of allelopathy of secalonic acid F on higher plants. Agronomy Journal, v. 93, n. 1, p. 72-79, 2001. 